\title{
Man-Made Forests and Elk in Coastal British Columbia1
}

\author{
by
}

\author{
Kim Brunt ${ }^{2}$
}

\begin{abstract}
The potential for integrated management of timber and elk in coastal forests is discussed. The basic habitat requirements of elk for food, security cover, thermal cover, and snow interception cover are presented and the influences of various common forestry practices on these requirements are examined. Clearcutting, slash burning, planting, noncommercial thinning, commercial thinning, species conversion, weeding, and fertilizing all strongly influence the ability of forests to satisfy elk requirements. In most instances, the impacts of these activities are neither all together good nor bad, and a team approach between forest and wildlife managers needs to be taken when planning forestry activities. A brief overview of the effects of elk on regenerating forests is presented and a potential solution is offered to the problem of browsing damage through the provision of alternative forage. Elk and wood production are compatible in the man-made forest if both forest and wildlife managers are willing to accept realistic compromises to achieve the goals of integrated management.
\end{abstract}

\section{Résumé}

Le potentiel d'aménagement intégré entre la matière ligneuse et le wapiti dans les forêts des côtes est abordé dans cet article. Les besoins de base pour le domaine du wapiti tel la nourriture, la protection sécuritaire, la protection thermique et le couvert permettant d'intercepter la neige sont présentés et les influences de différentes pratiques forestières courantes sur ces besoins sont étudiées. La coupe total, le brûlage des déchets d'abattage, la plantation, l'éclaircie pré-commerciale, l'éclaircie commerciale, l'éducation des peuplements, le contrôle des mauvaises herbes, la fertilisation ont tous une grande influence sur la capacité des forêts à satisfaire les besoins du wapiti. Dans la plupart des cas, l'impact de ces activitiés n'est ni favorable ou défavorable lorsque considéré dans son ensemble, mais une approche multi-disciplinaire entre les gestionnaire des forêts et de la faune, doit être prise lors de la planification des activités forestières. Un bref aperçu des effets du wapiti sur les forêts en régénération est abordé et une solution possible est apportée au problème du broutage, sous la forme d'une autre source de broutage. Le wapiti et la production et bois sont compatibles dans une forêt conçue par l'homme si les gestionnaires de la faune te des forêts s'entendent pour accepter des compromis réalistes afin d'atteindre les objectifs de l'aménagement intégré.

\section{Introduction}

Forestry activities for wood production, and elk habitat management to optimize elk production, probably will never be completely compatible. To move towards truly integrated resource management, we need to foster understanding of the requirements of both forest and wildlife habitat managers that encourages the compromises each must make when considering elk requirements in man-made forests. This is not meant to forecast a doom and gloom picture for forestrywildlife integration, but rather to acknowledge that although integration will hopefully be bloodless, it may not always be completely painless. It probably will cost something to maintain or enhance wildlife in man-made forests, and the economic and social benefits of the healthy wildife populations that result will be difficult to evaluate quantitatively.

1Paper given at the Working Group on Wildlife and Fish Habitat, Annual Meeting of the Canadian Institute of Forestry, Victoria, B.C. September 1986. 2Ministry of Environment and Parks, 2569 Kenworth Road, Nanaimo, B.C. V9T 4P7.
Since 1981, a jointly funded program by British Columbia's Ministries of Environment and Forests known as the Integrated Wildlife-Intensive Forestry Research (IWIFR) Program has examined the effects of forestry activities on Roosevelt elk (Cervus elaphus roosevelti) and black-tailed deer (Odocoileus hemionus columbianus) on Vancouver Island. This paper focuses on Roosevelt elk-forestry interactions in coastal habitats, but the general principles are applicable elsewhere.

\section{Elk Requirements}

Elk have three basic requirements that must be satisfied by their habitat: water, food and cover. The availability of water is not limiting to elk populations on Vancouver Island so this discussion is restricted to food and cover requirements.

Food, from available vegetation, supplies all of the energy, protein, minerals, and trace elements, and much of the moisture required by elk. Moist rich areas, aside from providing the most productive growing sites for forests, also 
produce abundant preferred elk forage. Other heavily used foraging areas include bogs or meadows, vegetated subalpine slides, and riparian areas.

Cover is provided by a combination of the vegetative and topographic characteristics of habitat and is usually classified under three general categories. Security cover provides a means of escape or a sense of protection from natural predators or humans from its ability to hide elk from view. Thermal cover offers shelter from climatic extremes. Relatively closed canopies intercept rain and excessive solar radiation, and entrap longwave radiation to maintain warmer temperatures in winter. Protection from wind is offered by tree stems and lower branches. Branches in the overstory of snow interception cover provide areas of shallower snow by intercepting and holding snow. Reduced snowpacks in snow interception cover stands provide elk access to forage which might otherwise be buried, as well as decreased energy costs of moving which increase dramatically with snow depth (Parker et al. 1984).

Generally, as tree size and canopy closure increase, the ability of the stand to provide forage decreases while its value as cover increases. As development proceeds past the recent-clearcut stage when forage production is greatest, stands generally supply security cover first, then both thermal and security cover, and finally snow interception cover as well (Figure 1). In some stands, natural thinning and pruning, or reduced understory density from increasing overstory canopy closure may reduce the stands ability to provide security cover.

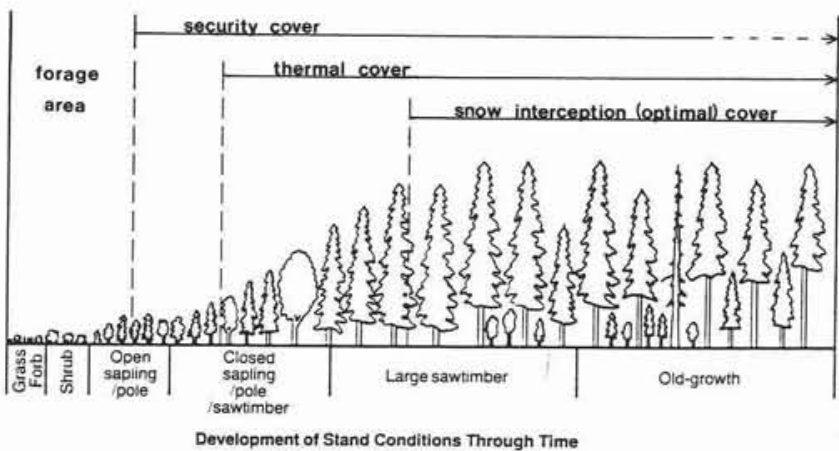

Figure 1. Generalized relationship of a stand's ability to provide forage and cover through time (modified from Wisdom et al. 1986).

Stands that satisfy security, thermal, and snow interception cover requirements are usually referred to as optimal cover. Optimal cover characteristics are generally not achieved until stands are in the mature or old-growth condition.

An important additional requirement of elk is that food and cover resources are distributed in time and space so that they can be efficiently exploited. A number of studies (reviewed by Witmer et al. 1985) have indicated reduced use by deer and elk of both forage and cover areas as the distance from their common edge increases. Elk use of forage and cover areas on Vancouver Island that are greater than $200 \mathrm{~m}$ from a forage/cover edge is extremely limited (Figure 2). Disproportionate use of edges by wildlife is generally attributable to the relatively greater floral diversity associated with edges, along with the need for easy access to habitats that satisfy the animals' requirements (Thomas et al. 1979). For elk, use of edges between relatively open forage areas and forested cover areas allows easy access to cover if the animals are disturbed while foraging, as well as less expenditure of energy in travel while moving between forage and cover areas.

\section{Forestry Impacts on Elk Habitat}

The most important influences affecting the quality, quantity, and arrangement of elk food and cover in coastal areas are forestry activities. Because elk survival and successful reproduction are dependent on habitat quality, forestry activities strongly influence the long-term performance of elk populations.

Most deer and elk winter ranges in coastal areas include old-growth forests which possess excellent winter forage availability and snow interception characteristics. These areas are often deferred from forest harvesting because of their wildlife values. The preservation of old growth for winter ranges remains one of the most contentious issues of forestry-wildlife interactions. In areas where deep, persistent snowpacks commonly occur, the retention of old growth to provide deer and elk winter range may be the only solution. However, where shallower snow accumulations are usual, options are available to manage young stands so that they may mimic old growth in their ability to satisfy winter range requirements (Nyberg et al. 1986).

As the supply of accessible old-growth timber diminishes, the need to manage second-growth forests intensively to supply future wood needs has become apparent. Many of the tools used in intensive forest management can improve elk habitat quality when applied with the basic ecological requirements of elk in mind. The exact quantitative relationships between most forestry activities and elk habitat quality are widely variable and, for the most part, currently unknown. Therefore, only general effects of some common coastal forestry practices are dealt with here.

\section{Clearcutting}

Complete removal of the overstory promotes growth of many herbaceous forage species. The abundant food source available in recent clearcuts has led some people to the blanket conclusion that all logging benefits deer and elk. Recent clearcuts, however, provide little security or thermal cover, and have no canopy to intercept snow. High forage production in clearcuts generally continues until canopy closure occurs in the regenerating stand ( 15 to 20 years after stand establishment). The majority of the forage/cover edges present in coastal forests are a result of clearcut logging, so

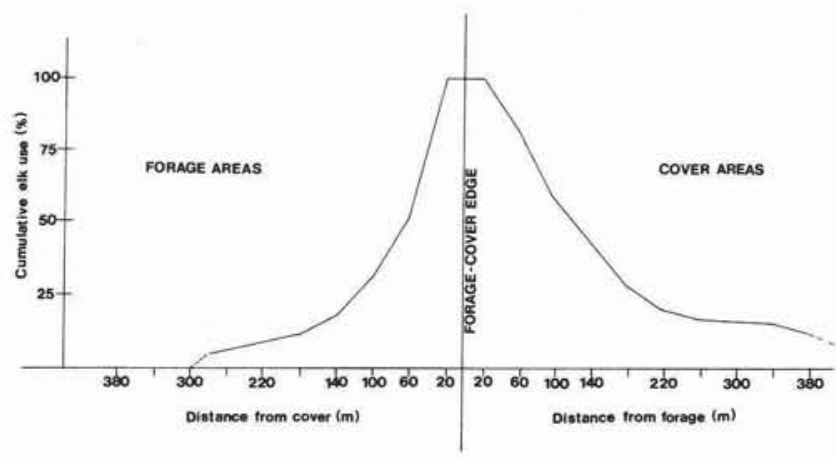

Figure 2. Elk use of forage and cover areas on Vancouver Island as related to distance from a forage - cover edge (modified from Youds et al. 1985). 
the size and spacing of clearcuts is critical if an easily exploitable supply of food and cover for elk is to be maintained across the landscape through time. Progressively clearcutting large areas over a short time produces little forage/cover edge and results in a relatively homogeneous area over which forage production declines at approximately the same time

Depending on the orientation of slash piles remaining after clearcutting relative to heavily used roads or other areas of human activity, they may provide an effective visual screen to promote elk use of a clearcut. Excessive slash however, can limit elk access to an area.

\section{Slash Burning}

Burning following clearcut logging reduces slash to enhance elk access to an area and provides space for growth of preferred forage species. The release of nutrients also increases soil productivity. Immediately following the fire, forage availability is generally very low as the above-ground portions of plants are usually destroyed. However, many early seral species quickly become established and, with regrowth of perennial herbs and shrubs, highly productive forage areas can result. Excessively hot fires may seriously limit an area's ability to provide forage by killing below ground portions of perennials and destroying the soil's organic layer.

Selective burning can be used to protect slash piles that may be providing beneficial security cover for elk that would otherwise be lost through broadcast burning

\section{Planting}

The selection of tree species and stocking density strongly influences the interval from logging until the new stand provides adequate cover. Slow growing trees planted at low density will take longer to reach canopy closure and therefore produce forage longer than densely planted stands of rapidly growing trees. Moist, rich sites generally yield high quantities of preferred elk forage, and when it is desirable to maintain forage production on these sites as long as possible, planting to wider spacing would delay canopy closure.

\section{Non-Commercial Thinning (Juvenile Spacing)}

First thinnings in coastal B.C. forests generally take place when stands are about 10 to 20 years old. Non-commercial thinning enhances forage production in a stand by increasing the amount of light, moisture, and nutrients available to the understory.

Security and thermal cover capabilities of the stand are temporarily reduced and snow interception is usually very low at the time of juvenile spacing. The overall effect is to shift development of the treated stand to an earlier seral stage which prolongs forage production and delays the development of suitable cover relative to an untreated stand.

An important unfavourable effect of non-commercial thinning is the resulting debris which reduces the area available for forage species to grow and greatly increases the energy that elk must use in travelling through the area. The estimated costs of movement over obstacles increases dramatically as the depth and number of obstacles encountered increases (Parker et al. 1984). Slash deterioration rates depend mostly on tree size at the time of thinning and pre- and post-spacing density. Although elk access may be unaffected or limited for a short time only in stands spaced at 10 to 20 years, debris resulting from spacing in stands 20 to 40 years old poses a much more serious problem. Large tracts of this "backlog spacing" in the Sayward Provincial Forest on Vancouver Island which were treated in the late 1970's retain impenetrable slash, exceeding $2 \mathrm{~m}$ in depth in some areas, 10 years after treatment. Where backlog spacing is essential, directional falling or debris removal or treatment by bucking, trailing, or piling would reduce the impact. While it is generally considered a practice of the past, changes in forest management priorities and available funds will undoubtedly result in localized backlog spacing in the future. The existence of a market for the smaller timber produced would alleviate most debris problems of backlog spacing.

\section{Commercial Thinning}

Multiple entries into stands prior to final rotation age will probably become more common in the future if favourable prices for small logs can be obtained. Forage production following commercial thinning, similar to that following noncommercial thinning, is generally enhanced through an increase in light, moisture, and nutrients available to understory species. The degree of forage response generally will be related to the degree of thinning applied to the stand with more heavily thinned stands providing relatively greater quantities of forage. The increase in forage production after commercial thinning will not usually be as dramatic as that following non-commercial thinning since certain species may have disappeared from the understory during the period of canopy closure (Nyberg et al., in prep.). The increase in forage production as a result of commercial thinning will generally persist until canopy closure occurs once again.

Commercial thinning reduces the ability of the stand to provide cover for a short time. However, thinning eventually enhances the ability of the stand to intercept snow because it stimulates growth of wider crowns and stronger branches (Bunnell et al. 1985).

\section{Species Conversion}

The conversion (through logging and planting) of sites occupied by non-commercial species (usually red alder Alnus rubra - in coastal forests) to coniferous stands, affects elk habitat in several ways. A long-term benefit of the process is the replacement of a deciduous overstory with relatively poor thermal and snow interception cover capabilities, with a coniferous overstory which is much better at intercepting snow. Red alder however, fixes nitrogen and returns nutrients to the soil through litterfall (Krajina et al. 1982) which enhances an abundant understory of forage species preferred by elk. Forage production would be increased immediately after removal of the overstory but would eventually be lower than pre-treatment levels once canopy closure occurred in the new conifer stand. Herbicide treatments which often accompany site conversion reduce forage production and may lead to browsing damage of planted conifers when elk turn to the only remaining forage in traditionally heavily-used feeding areas.

\section{Weeding}

Removing understory species which compete with crop trees not only reduces forage availability in the short term, but also encourages tree growth which reduces the time during which the stand provides forage. Although spacing generally lengthens the interval until cover conditions of a stand are optimal, weeding can be considered to reduce the period of forage production of a stand by hastening canopy closure. 


\section{Fertilization}

The increase in forage quality from urea fertilization is generally short-lived, lasting 2 or 3 years (Ash and Bendell 1979). However, increases in forage quantity relative to unfertilized stands will usually persist $5-10$ years as the increased growth immediately after treatment gives forage plants a competitive advantage (Nyberg et al., in prep.). Tree growth is also enhanced so that cover and snow interception capabilities of the stand are attained at an earlier age than in unfertilized stands.

\section{Elk Impacts on Forests}

Increased use of forest lands by hunters and nonconsumptive users can be expected in areas where elk occur. The resulting increases in theft, vandalism and misuse of fire that may occur have long been recognized (Bunnell and Dumont 1973). More serious economic problems often arise from elk damage to regenerating stands. Three types of damage commonly occur: horning, bark-stripping, and browsing. Horning damage is usually limited to a very few trees damaged by adult bulls thrashing small trees with their antlers during the breeding season. Bark-stripping also is usually of limited importance and is often restricted to winter ranges where elk strip bark to reach the nutritious cambium layer by scraping their lower incisors up the tree. Trees are not usually completely girdled and generally survive this indignity.

Browsing loss of regenerating conifers by elk in coastal B.C. is probably not as important as browsing by deer, but can be serious locally. Attempts to deter wildlife browsing with chemical repellants are generally unsuccessful in wet coastal areas. Protective tubing over tree leaders is usually successful but is expensive on large areas. Another option is forage seeding which not only improves a clearcut's ability to provide preferred elk forage, but may also reduce browsing damage to crop trees. Seeding of grasses and legumes to improve big game habitat was first attempted in Oregon in 1950 (Ramsey and Krueger 1986). The mixtures that have been developed in Oregon are currently being used for both brush control and to provide alternative forage to reduce browsing losses. Klingler (1982), however, reported that grasses planted in clearcuts apparently competed for moisture and nutrients in coastal Oregon to effect crop tree growth somewhat.

Trials of forage seeding on Vancouver Island are planned to determine whether the gains realized from reduced browsing damage through providing alternative forage outweigh loss of tree growth that may occur through competition. Forage seeding, especially in combination with fertilization, may provide a high quality alternative food for elk to allow crop tree leaders to grow beyond browsing height.

\section{Summary}

Intensive management in the man-made forest is not altogether good or bad for elk in coastal areas. Some treatments tend to enhance or maintain the forage producing capabilities of a stand while others may improve the cover characteristics, or reduce the interval until the stand provides cover after harvesting. Treatments, however, should not be considered individually as improving either the forage or cover characteristics of isolated stands. Elk require both food and cover resources distributed so that they can be efficiently exploited. Forest management practices have the potential to create and sustain a favourable mosaic of forage and cover areas interspersed across the landscape. For example, on elk ranges where forage-producing areas are limited, wide spacing or clearcutting of strategically placed blocks would provide forage to enhance the overall quality of the area as elk habitat. Where cover is limiting, fertilization or dense stocking of crop trees may increase elk use and improve the elk production capability of the area. Planning forestry treatments in time and space to provide both forage and cover within $200 \mathrm{~m}$ of any point on elk ranges would improve habitat quality substantially.

Elk browsing damage to regenerating stands in coastal areas may be reduced by providing alternative forage through seeding grasses and legumes in clearcuts. Tests of the feasibility of this approach on Vancouver Island are currently planned.

Coordinating wildlife and forest management in manmade forests is a difficult but rewarding challenge facing resource managers. Continued research will clarify and quantify many of the relationships that remain unclear so that effective and truly integrated management can be carried out.

\section{References}

Ash, A.N. and J.F. Bendell. 1979. Trials of nitrogen fertilization on foods of blue grouse. J. Wildl. Manage. 43:503-508.

Bunnell, F.L. and W.E. Dumont. 1973. Foresters, forestry and wildlife. For. Chron. 49: 66-70.

, R.S. McNay and C.C. Shank. 1985. Trees and snow: the deposition of snow on the ground - a review and quantitative synthesis. Research, BC Min. Environ, and Min. For. IWIFR-17. Victoria, B.C

Klingler, G.E. 1982. Effect of grass-legume competition on shrub and hardwood invasion in newly harvested clearcuts. Unpubl. rep. Alsea Ranger District, Siuslaw N.F., Oregon.

Krajina, V.J., K. Klinka and J. Worrall. 1982. Distribution and ecological characteristics of trees and shrubs of British Columbia. Fac. For., Univ. of B.C., Vancouver.

Nyberg, J.B., L.D. Peterson and L.S. Stordeur. (in prep.) Intensive forestry effects on Vancouver Island deer and elk forage. Job Completion Report. IWIFR-EP934.01. B.C. Min. For. and Lands, and Min. Environ, and Parks, Victoria, B.C.

, F.L. Bunnell, D.W. Janz and R.M. Ellis. 1986. Managing young forests as black-tailed deer winter ranges. BC Min. For., Land Manage. Rep. 37. Victoria, B.C.

Parker, K.L., C.T. Robbins and T.A. Hanley. 1984. Energy expenditures for locomotion by mule deer and elk. J. Wildl. Manage. 48:474-488.

Ramsay, K.J. and W.C. Krueger. 1986. Grass-legume seeding to improve winter forage for Roosevelt elk: a literature review. Special Rep. 763, Agric. Exp. Station, Oregon State Univ., Corvallis, Oreg.

Thomas, J.W., C. Maser and J.E. Rodiek. 1979. Edges. In Wildlife Habitats in Managed Forests. J.W. Thomas (ed). USDA Agric. Handbook No. 553, p. 48-59.

Wisdom, M.J., L.R. Bright, C.G. Carey, W.W. Hines, R.J. Pederson, D.A. Smithey, J.W. Thomas and G.W. Witmer. 1986. A model to evaluate elk habitat in western Oregon. USDA Publ. No. R6-F\&WL-219-1986.

Witmer, G.W., M. Wisdom, E.P. Harshman, R.J. Anderson, C. Carey, M.P. Kuttel, I.D. Luman, J.A. Rochell, R.W. Scharpf and D. Smithey. 1985. Deer and elk. In Management of wildlife and fish habitats in forests of western Oregon and Washington. Part I - Chapter Narratives. E. Reade Brown (ed). USDA Publ. No. R6-F\&WL-192-1985, p. 231-258

Youds, J., K. Brunt and D. Becker. 1985. Vancouver Island Roosevelt elk/intensive forestry interactions: progress report 1981-1984. Research, B.C. Min. Environ. and Min. For. IWIFR21. Victoria, B.C. 